\title{
Factors Associated with Needle Stick and Sharp Injuries Among Healthcare Workers in North East Ethiopia
}

This article was published in the following Dove Press journal: Risk Management and Healthcare Policy

\section{Getaw Walle Bazie (1) \\ Department of Epidemiology and Biostatistics, School of Public Health, College of Medicine and Health Sciences, Wollo University, Dessie, Ethiopia}

Background: Percutaneous exposure to blood and body fluids through contaminated needle sticks and sharps are serious occupational hazards for morbidity and mortality from infections from blood-borne pathogens among healthcare workers. However, limited studies have been conducted to identify factors associated with needle stick and sharp injuries among healthcare workers in the study area. Therefore, this study aimed at identifying factors associated with needle stick and sharp injuries among healthcare workers.

Methods: Institution-based cross-sectional study was conducted among healthcare workers at health facilities in Dessie from January to March 2018. A simple random sampling technique was used to recruit 362 healthcare workers. Data were collected using a structured self-administered questionnaire. The association between dependent and independent variables was checked using binary logistic regression and $p$-value $\leq 0.05$ was used as a cut-off point for significance.

Results: The entire work time and one-year prevalence of needle stick and sharp injury among healthcare workers were $60.2 \%$ and $40.1 \%$, respectively. Working in private hospital $(\mathrm{AOR}=9.619,95 \% \mathrm{CI}: 2.476,27.373)$, working in private clinic $(\mathrm{AOR}=3.308,95 \% \mathrm{CI}$ : $1.038,8.506)$, less work experience $(\mathrm{AOR}=2.762,95 \% \mathrm{CI}: 1.381,4.521)$, higher workload $(\mathrm{AOR}=3.794,95 \% \mathrm{CI}: 2.268,6.346)$ and all-time availability of sharp storage and disposal containers $(\mathrm{AOR}=0.435,95 \% \mathrm{CI}$ : $0.215,0.879)$ were significant predictors of needle stick and sharp injuries.

Conclusion: Prevalence of needle stick and sharp injury was high. Working in private health institutions, less work experience, higher workload and all-time availability of sharp storage and disposal containers were significant predictors of needle stick and sharp injuries. Therefore, efforts have to be made to reduce the workload of healthcare workers and to available sharp storage and disposal containers all the time in the workplaces.

Keywords: associated factors, Ethiopia, healthcare workers, needle stick and sharp injuries

\section{Introduction}

Needle stick and sharp injuries are defined as an accidental skin penetrating wound caused by hollow-bore needles such as hypodermic needles, blood collection needles, intravenous (IV) catheter stylets, scalpels, scissors, suturing materials and broken ampoules. $^{1,2}$ Exposure among healthcare workers is caused by percutaneous injuries with sharp objects contaminated with blood or body fluids and can cause substantial health consequences and psychological distress for healthcare workers and their loved ones. ${ }^{3}$ The pathogens most commonly transmitted to healthcare workers in occupational
Correspondence: Getaw Walle Bazie Department of Epidemiology and Biostatistics, School of Public Health, College of Medicine and Health Sciences, Wollo University, Dessie, Ethiopia

$\mathrm{Tel}+251910364598$

Email getaw4jesus@gmail.com
Risk Management and Healthcare Policy 2020:I3 2449-2456 
settings are the Hepatitis B and C viruses (HBV and HCV) and the human immunodeficiency virus (HIV). ${ }^{4,5}$

Healthcare workers (HCWs) in developing countries are particularly at increased risk of infections from bloodborne pathogens through occupational exposure because of the high prevalence of such pathogens in their countries as well as the lack of basic personal protective equipment (PPE), poor adherence to safety practices and less likely to report and use post-exposure prophylaxis (PEP) and also due to enormous popularity and overuse of injectable therapy. ${ }^{6-8}$

Accidental needle sticks and sharp injuries to healthcare workers (HCWs) continue to have a significant problem in the healthcare system owing to the associated health risk of acquiring infections such as hepatitis B (HBV), hepatitis C (HCV), human immune deficiency virus and other blood-borne pathogens. ${ }^{9}$ World health organization (WHO) has reported that worldwide $2.5 \%$ of HIV and $40 \%$ of hepatitis B and C cases among healthcare workers were due to occupational exposures. ${ }^{1,5,10}$

The risk of acquiring these diseases after accidental sharps injuries was $30 \%$ for hepatitis B (HBV), $3 \%$ for hepatitis $\mathrm{C}(\mathrm{HCV})$, and $0.3 \%$ for human immunodeficiency virus (HIV). ${ }^{4,11}$ Such proportion can no longer be ignored. Therefore, in the holistic effort to reverse the spread of the disease from occupational exposures, understanding the problems that put the healthcare workers (HCWs) these risks are a contemporary and burning issue. ${ }^{10-13}$

Preventable needle stick injuries occur most commonly in Africa and Asia. In some regions of Africa and Asia close to half of the hepatitis $\mathrm{B}$ and $\mathrm{C}$ infections among healthcare workers are attributable to contaminated sharps. These are the settings where healthcare workers are at greatest risk for infection because of the prevalence of infection among patients and where Hepatitis B immunization is not a standard. However, very few efforts have been undertaken to raise awareness of healthcare workers and hospital managers. Healthcare workers in Africa suffer on average two to four needle stick injuries per year and over half of the hospitalized patients in South Africa are HIV positives. ${ }^{5,14,15}$ Studies done in different countries indicated that the magnitude of needle stick and sharp injuries among healthcare workers was very high., ${ }^{2,4-6,16-20}$

Although different studies conducted in some parts of Ethiopia, ${ }^{3-5,9,21-23}$ at a country level the number of health professionals affected with needle stick and sharp injuries remain unknown. The number of health institutions increased dramatically in Dessie city. However, there are few studies conducted that indicate factors associated with needle stick and sharp injuries in the study area. Thus, this study was conducted to identify factors associated with needle stick and sharp injuries among healthcare workers at Dessie City public and private health facilities.

\section{Materials and Methods Study Design and Area}

An institutional-based cross-sectional study was conducted among healthcare workers both at public and private health facilities of Dessie city. The study was conducted among healthcare workers at Dessie city health institutions from January to March 2018. Dessie city is located $401 \mathrm{~km}$ from Addis Ababa, the capital city of Ethiopia.

\section{Population}

All healthcare workers who worked at least one year and above in the selected health facilities were included in the study. These workers were doctors, anesthetists, health officers, nurses, midwives, laboratory personnel, and cleaners. Those healthcare workers in which their day to day activity does not make them prone to exposure to sharp injuries (Drug dispensers, Physiotherapists, Radiographers) were excluded from the study.

\section{Study Variables}

The dependent variable of this study was needle stick and sharp injuries. The independent variables were sociodemographic variables; age, sex, job category/profession, level of education, work experience, and working institution; work environment/organizational variables: health safety training, length of working hours/week, the existence of safety guideline, availability of sharp disposal containers, working department, working night shift, workload, overprescribed injectable medication and workplace supervision and behavioral variables: needle recapping, awareness on disease transmission by sharp injuries, reporting pattern and use of personal protective equipment.

\section{Sample Size and Sampling Procedures}

The sample size was determined using the single population proportion formula. It was computed by considering $31 \%$ of the past 12 months' prevalence of needle stick and sharp injury; ${ }^{23} 95 \%$ confidence level, and 0.05 margin of error. This was found to be 329 and adding a 10\% allowance for non-response rate, the total sample size became 
362. Simple random sampling through lottery technique was employed to select three hospitals (from five hospitals), four health centers (from eight) and four private clinics (from eight) from a total of 21 health facilities. The proportional allocation was made to determine the number of respondents from each selected health institution and then a systematic random sampling method was conducted to select the respondents by using the list of workers in each organization as a sampling frame.

\section{Data Collection Procedures}

A structured and pre-tested self-administered questionnaire was used to collect data among the selected healthcare workers. The questionnaire includes socio-demographic variables such as age, sex, job category/profession, level of education, work experience, and working institution, work environment/organizational variables such as health safety training, length of working hours/week, the existence of safety guideline, availability of sharp disposal containers, working department, working night shift, workload, overprescribed injectable medication and workplace supervision and behavioral variables such as needle recapping, awareness on disease transmission by sharp injuries, reporting pattern and use of personal protective equipment.

The questionnaire was first prepared in English. The English version questionnaire was translated to the Amharic version and was retranslated back to English to check its consistency. Participants were given orientation about the aim of the study and procedure on how to fill the questionnaires. The data quality was assured by properly designing and pre-testing the questionnaire, training of the data collectors, categorization and coding of the questions. The one-day training was given to data collectors before the initiation of the data collection. The questionnaire was pre-tested on $5 \%$ of the total sample out of the study area that has similar sociodemographic characteristics with the study health centers. After pre-testing of the questionnaire, modifications were made on arrangement, clarity, consistency and completeness of the questions before the actual procedures begin.

\section{Data Processing and Analysis}

After data collection, each questionnaire was checked visually for completeness. The corresponding code number was written carefully at each margin. Data cleaning was performed to check for accuracy, consistency and missing values and variables. The template scheme for data entry was developed and pre-tested for ranges, skipping patterns and allowed legal values by entering 5\% pre-test questionnaires. The cleaned data were entered into EpiData version 3.1 and was exported to SPSS version 23 statistical software packages for further analysis. Descriptive statistics like frequency tables, percentages and figures were used to describe the study population. Any errors identified at this stage were corrected by reviewing the original data using the code numbers. The bi-variable analysis was conducted primarily to identify individual variable which has an association with the dependent variable. Variables which have an association with the dependent variable at P-value $\leq 0.2$ in the bivariable logistic regression were candidate variables to enter to the multivariable logistic regression. The backward stepwise regression method was used to select the variables. Variables with p-values $\leq 0.05$ were used to identify independent factors of needle stick and sharp injuries. The degree of association between independent and dependent variables was assessed using crude and adjusted odds ratios, and their statistical significance was assessed at a $95 \%$ confidence interval. Adequacy of the model was assessed using Hosmer and Lemeshow goodness of fit to test whether the required assumptions for the application of multivariable logistic regression are fulfilled.

\section{Ethical Considerations}

The study was conducted following the Declaration of Helsinki. Ethical clearance was obtained from the Institutional Review board of the College of Medicine and Health Sciences, Wollo University. Permission letter to conduct the study was obtained from the Dessie city administration health office and respective health institutions. Written informed consent was obtained from healthcare workers after they were informed about the objectives and procedures of the study. Their rights to refuse participation any time they want were assured. For this purpose, a onepage consent letter was attached as a cover page of each questionnaire stating the general objective of the study and issues of confidentiality that was discussed by the data collectors before proceeding to the data collection.

\section{Results}

\section{Socio-Demographic Characteristics of Participants}

Three hundred thirty-seven healthcare workers responded fully to the self-administered questionnaire providing a response rate of 93\%. Among them 202 (59.9\%) were females, $198(40.6 \%)$ were from government health 
institutions. The mean $( \pm \mathrm{SD})$ age of respondents was $30.3( \pm$ 6.12 ) years and 210 (63.3\%) participants were below the mean age (Table 1).

\section{Organizational/Environmental}

\section{Characteristics}

Sixty-nine $(20.5 \%)$ of healthcare workers are working in the medical ward department. Healthcare workers working in the night shift accounted for $82.5 \%$ and healthcare workers working more than 40 hours a week accounted for $72.1 \%$ (Table 2).

Table I Socio-Demographic Characteristics of Healthcare Workers at Dessie City Administration Health Institutions, 2018

\begin{tabular}{|c|c|c|c|}
\hline Variables & Category & Number & Percent \\
\hline $\begin{array}{l}\text { Type of health } \\
\text { institution }\end{array}$ & $\begin{array}{l}\text { Government } \\
\text { Hospital } \\
\text { Private Hospitall } \\
\text { Government H/ } \\
\text { Center } \\
\text { Private Clinic }\end{array}$ & $\begin{array}{l}137 \\
81 \\
61 \\
58\end{array}$ & $\begin{array}{l}40.6 \\
24 \\
18.1 \\
17.2\end{array}$ \\
\hline Sex & $\begin{array}{l}\text { Male } \\
\text { Female }\end{array}$ & $\begin{array}{l}135 \\
202\end{array}$ & $\begin{array}{l}40.1 \\
59.9\end{array}$ \\
\hline Age & $\begin{array}{l}20-24 \text { Years } \\
25-29 \text { Years } \\
30-34 \text { Years } \\
35-39 \text { Years } \\
40-44 \text { Years } \\
\geq 45 \text { Years }\end{array}$ & $\begin{array}{l}38 \\
110 \\
77 \\
56 \\
32 \\
24\end{array}$ & $\begin{array}{l}13.3 \\
32.6 \\
22.8 \\
16.6 \\
9.5 \\
7.1\end{array}$ \\
\hline Educational status & $\begin{array}{l}\text { Primary }^{1-8} \\
\text { Secondary } \\
\text { Diploma } \\
\text { Degree and above }\end{array}$ & $\begin{array}{l}8 \\
18 \\
227 \\
84\end{array}$ & $\begin{array}{l}2.8 \\
5.3 \\
67.4 \\
24.9\end{array}$ \\
\hline Profession & $\begin{array}{l}\text { Cleaner } \\
\text { Clinical/B.Sc Nurse } \\
\text { Health officer } \\
\text { Midwife } \\
\text { Medical doctor } \\
\text { Laboratory } \\
\text { personnel } \\
\text { Surgeon } \\
\text { Obstetrician } \\
\text { Others* }\end{array}$ & $\begin{array}{l}28 \\
191 \\
21 \\
35 \\
10 \\
34 \\
\\
6 \\
4 \\
8\end{array}$ & $\begin{array}{l}8.3 \\
56.7 \\
6.2 \\
10.4 \\
3.0 \\
10.1 \\
\\
1.8 \\
1.2 \\
2.4\end{array}$ \\
\hline Work experience & $\begin{array}{l}<5 \text { years } \\
5-10 \text { years } \\
>10 \text { years }\end{array}$ & $\begin{array}{l}152 \\
125 \\
60\end{array}$ & $\begin{array}{l}45.1 \\
37.1 \\
17.8\end{array}$ \\
\hline
\end{tabular}

Note: Others $*=$ Anesthetist, Optometrist, Environmental health professionals. Abbreviation: ETB, Ethiopian birr.
Table 2 Organizational/Environmental Characteristics of Healthcare Workers at Dessie City Administration Health Institutions, 2018

\begin{tabular}{|c|c|c|c|}
\hline Variables & Category & Number & Percent \\
\hline Working department & $\begin{array}{l}\text { Pediatric } \\
\text { ward } \\
\text { Maternity } \\
\text { ward } \\
\text { Laboratory } \\
\text { unit } \\
\text { Operation } \\
\text { room } \\
\text { Medical ward } \\
\text { Surgical ward } \\
\text { Injection } \\
\text { room } \\
\text { Waste } \\
\text { handler unit } \\
\text { Others** }\end{array}$ & $\begin{array}{l}54 \\
52 \\
36 \\
43 \\
69 \\
64 \\
26 \\
29 \\
7\end{array}$ & $\begin{array}{l}16 \\
15.4 \\
10.7 \\
12.8 \\
20.5 \\
19 \\
7.7 \\
8.6 \\
2.1\end{array}$ \\
\hline Working night shift & $\begin{array}{l}\text { Yes } \\
\text { No }\end{array}$ & $\begin{array}{l}278 \\
59\end{array}$ & $\begin{array}{l}82.5 \\
17.5\end{array}$ \\
\hline Working hours per week & $\begin{array}{l}\text { Up to } 40 \\
\text { hours } \\
\text { More than } 40 \\
\text { hours }\end{array}$ & $\begin{array}{l}93 \\
243\end{array}$ & $\begin{array}{l}27.6 \\
72.1\end{array}$ \\
\hline $\begin{array}{l}\text { Number of patients served } \\
\text { per day }\end{array}$ & $\begin{array}{l}\text { Above the } \\
\text { mean }^{28} \\
\text { Below the } \\
\text { mean }^{28}\end{array}$ & $\begin{array}{l}193 \\
144\end{array}$ & $\begin{array}{l}57.3 \\
42.7\end{array}$ \\
\hline $\begin{array}{l}\text { Training on infection } \\
\text { prevention }\end{array}$ & $\begin{array}{l}\text { Yes } \\
\text { No }\end{array}$ & $\begin{array}{l}118 \\
219\end{array}$ & $\begin{array}{l}35 \\
65\end{array}$ \\
\hline $\begin{array}{l}\text { Availability of waste } \\
\text { disposal container }\end{array}$ & $\begin{array}{l}\text { Not available } \\
\text { Some times } \\
\text { All the time }\end{array}$ & $\begin{array}{l}29 \\
68 \\
243\end{array}$ & $\begin{array}{l}8.6 \\
20.2 \\
71.2\end{array}$ \\
\hline $\begin{array}{l}\text { Supervised by concerned } \\
\text { body }\end{array}$ & $\begin{array}{l}\text { Yes } \\
\text { No }\end{array}$ & $\begin{array}{l}190 \\
147\end{array}$ & $\begin{array}{l}56.4 \\
43.6\end{array}$ \\
\hline
\end{tabular}

Note: Others ${ }^{* *}=$ Pharmacy unit, outpatient department and dermatology unit.

\section{Behavioral Characteristics}

One hundred sixty-three (48.4\%) of healthcare workers rated that they are at high risk of sustaining needle stick and sharp injuries. Those healthcare workers who reported that they are recapping needle accounts for $51.9 \%$ (Table 3 ).

\section{The Magnitude of Needle Stick and Sharp Injuries}

About 203 (60.2\%) healthcare workers experienced needle sticks and sharp injuries in their lifetime. Among these, 89 $(43.8 \%)$ sustained injury only once in their lifetime. About 
Table 3 Behavioral Characteristics of Healthcare Workers at Dessie City Administration Health Institutions, 2018

\begin{tabular}{|c|c|c|c|}
\hline Variables & Category & Number & Percent \\
\hline $\begin{array}{l}\text { Concerned about needle } \\
\text { stick and injuries }\end{array}$ & $\begin{array}{l}\text { Yes } \\
\text { No }\end{array}$ & $\begin{array}{l}296 \\
41\end{array}$ & $\begin{array}{l}87.8 \\
12.2\end{array}$ \\
\hline $\begin{array}{l}\text { Needle stick injuries } \\
\text { avoidable }\end{array}$ & $\begin{array}{l}\text { Yes } \\
\text { No }\end{array}$ & $\begin{array}{l}200 \\
137\end{array}$ & $\begin{array}{l}59.3 \\
40.7\end{array}$ \\
\hline $\begin{array}{l}\text { Rate needle stick/sharps } \\
\text { injuries risk }\end{array}$ & $\begin{array}{l}\text { Low risk } \\
\text { Moderate } \\
\text { risk } \\
\text { High risk }\end{array}$ & $\begin{array}{l}91 \\
82 \\
163\end{array}$ & $\begin{array}{l}27 \\
24.3 \\
\\
48.4\end{array}$ \\
\hline Recapping needle & $\begin{array}{l}\text { Yes } \\
\text { No }\end{array}$ & $\begin{array}{l}175 \\
162\end{array}$ & $\begin{array}{l}51.9 \\
48.1\end{array}$ \\
\hline $\begin{array}{l}\text { Personal protective } \\
\text { equipment uses }\end{array}$ & $\begin{array}{l}\text { Yes } \\
\text { No }\end{array}$ & $\begin{array}{l}238 \\
99\end{array}$ & $\begin{array}{l}70.6 \\
29.4\end{array}$ \\
\hline $\begin{array}{l}\text { Disease transmitted by } \\
\text { needle stick/sharp injury }\end{array}$ & $\begin{array}{l}\text { HIVIAIDS } \\
\text { Hepatitis B } \\
\text { Hepatitis C } \\
\text { Malaria }\end{array}$ & $\begin{array}{l}219 \\
75 \\
43\end{array}$ & $\begin{array}{l}65 \\
22.3 \\
12.7\end{array}$ \\
\hline $\begin{array}{l}\text { Report injury to concerned } \\
\text { body }\end{array}$ & $\begin{array}{l}\text { Yes } \\
\text { No }\end{array}$ & $\begin{array}{l}78 \\
124\end{array}$ & $\begin{array}{l}38.6 \\
61.4\end{array}$ \\
\hline Reason for none reporting & $\begin{array}{l}\text { Thought not } \\
\text { important } \\
\text { Fear of } \\
\text { stigma } \\
\text { Patient was } \\
\text { low risk }\end{array}$ & $\begin{array}{l}71 \\
6 \\
47\end{array}$ & $\begin{array}{l}57.3 \\
4.8 \\
37.9\end{array}$ \\
\hline
\end{tabular}

$143(40.1 \%)$ healthcare workers experienced needle stick and sharp injuries in the last 12 months. Needles caused about $60.4 \%$ injuries. Regarding how injury was experienced, $36 \%$ of injuries were experienced during surgery and suturing. About $66.3 \%$ of injuries were from unknown health status of source patients.

\section{Factors Associated with Needle Stick and Sharp Injuries}

After controlling for confounders on multivariable logistic regression, type of working institution, work experience, workload (number of patients served per day) and availability of sharp storage and disposal container were significantly associated with needle stick and sharp injuries.

Healthcare workers working in private hospitals were 9.62 times more likely to experience needle stick and sharp injuries than those working in government health centers (AOR $=9.619,95 \%$ CI: 2.476, 27.373). Healthcare workers working in private clinics were 3.3 times more likely to experience needle stick and sharp injuries than those working in government health centers (AOR = 3.308, 95\% CI: 1.038, 8.506). Healthcare workers with work experience of fewer than five years were 2.76 times more likely to experience needle stick and sharp injuries as compared to those who had work experience for more than ten years $(\mathrm{AOR}=2.762,95 \%$ CI: 1.381, 4.521). Healthcare workers providing healthcare services for more than the mean (28 patients per day) were 3.80 times more likely to experience needle stick and sharp injuries than healthcare workers serving below the mean $(\mathrm{AOR}=3.794,95 \%$ CI: 2.268, 6.346). Healthcare workers who had sharp storage and disposal container all the time in their workplace were $56.5 \%$ times less likely to experience needle stick and sharp injuries than those who did not have (AOR $=0.435,95 \%$ CI: 0.215, 0.879) (Table 4).

\section{Discussion}

The study was aimed at identifying factors associated with needle stick and sharp injuries among healthcare workers in health facilities at Dessie city, Ethiopia. Type of working institution, work experience, workload (number of patients served per day) and availability of sharp storage and disposal container were significantly associated with needle stick and sharp injuries.

The study revealed that the overall work time prevalence of needle stick and sharp injuries among healthcare workers working in Dessie city administration health institutions was $60.2 \%$. This finding is consistent with a study done in Bahir Dar where the prevalence is $59 \%{ }^{5}$ lower than a study done in Addis Ababa hospitals (66.6\%). ${ }^{4}$ The difference might be due to the type of health institutions included in the study. The study in Addis Ababa was among healthcare workers working in hospitals but this study includes both government hospitals and health centers, and private hospitals and clinics. Therefore, due to the workload and increased diagnostic and therapeutic interventional procedures that lead to contact with sharps in hospitals, the prevalence might be reduced when health centers and clinics are included. The result is higher than a study done in Eastern Ethiopia (30.5\%), ${ }^{9}$ Hawassa city, Southern Ethiopia $(35.8 \%)^{21}$ and Gondar city $(31 \%){ }^{22}$ The difference might be due to the involvement of private health institutions in this study as workload is usually higher than government health institutions especially health centers and workload is associated with needle stick and sharp injuries. The one-year prevalence of 
Table 4 Factors Associated with Needle Stick and Sharp Injuries Among Healthcare Workers at Dessie City Administration Health Institutions, 2018

\begin{tabular}{|c|c|c|c|c|c|}
\hline \multirow[t]{2}{*}{ Variables } & \multirow[t]{2}{*}{ Category } & \multicolumn{2}{|c|}{$\begin{array}{l}\text { Needle Stick and } \\
\text { Sharp Injury Status }\end{array}$} & \multirow[t]{2}{*}{ COR $(95 \% \mathrm{Cl})$} & \multirow[t]{2}{*}{ AOR $(95 \% \mathrm{Cl})$} \\
\hline & & Yes & No & & \\
\hline Type of Working institution & $\begin{array}{l}\text { Government } \\
\text { Hospital } \\
\text { Private Hospital } \\
\text { Private Clinic } \\
\text { Government H/ } \\
\text { Center }\end{array}$ & $\begin{array}{l}78 \\
57 \\
39 \\
28\end{array}$ & $\begin{array}{l}59 \\
\\
24 \\
19 \\
33\end{array}$ & $\begin{array}{l}\text { I.024 }(0.669,1.566) \\
2.933(I .633,5.27 I) \\
I .106(0.793, I .543) \\
I\end{array}$ & $\begin{array}{l}1.347(0.523,3.466) \\
9.619(2.476,27.373) \\
3.308(1.038,8.506) \\
1\end{array}$ \\
\hline Work Experience & $\begin{array}{l}\text { Less than } 5 \text { Years } \\
5-10 \text { Years } \\
\text { More than } 10 \text { Years }\end{array}$ & $\begin{array}{l}82 \\
77 \\
41\end{array}$ & $\begin{array}{l}70 \\
48 \\
19\end{array}$ & $\begin{array}{l}I .417(1.048, I .916) \\
I .356(0.922,1.921) \\
I\end{array}$ & $\begin{array}{l}2.762(I .38 I, 4.52 I) \\
0.85 I(0.4 I 7, I .740) \\
I\end{array}$ \\
\hline Number of patients served per day & $\begin{array}{l}\text { Below the mean } \\
(<28) \\
\text { Above the mean } \\
(>28)\end{array}$ & $\begin{array}{l}53 \\
147\end{array}$ & $\begin{array}{l}93 \\
46\end{array}$ & $\begin{array}{l}\text { I } \\
3.568(2.268,5.670)\end{array}$ & $\begin{array}{l}\text { I } \\
3.794(2.268,6.346)\end{array}$ \\
\hline $\begin{array}{l}\text { Availability of sharp storage and disposal } \\
\text { container }\end{array}$ & $\begin{array}{l}\text { All the time } \\
\text { Some times } \\
\text { No }\end{array}$ & $\begin{array}{l}133 \\
45 \\
22\end{array}$ & $\begin{array}{l}107 \\
23 \\
7\end{array}$ & $\begin{array}{l}3.143(1.343,7.357) \\
1.957(1.184,3.233) \\
\text { I }\end{array}$ & $\begin{array}{l}0.435(0.215,0.879) \\
0.73 \text { I }(0.266,2.006) \\
\text { I }\end{array}$ \\
\hline
\end{tabular}

Abbreviations: $\mathrm{AOR}$, adjusted odds ratio; $\mathrm{Cl}$, confidence interval; $\mathrm{COR}$, crude odds ratio.

exposure is also higher than the study done in different parts of the country $(40.1 \%){ }^{23}$

Regarding factors associated with needle stick and sharp injuries, healthcare workers working in private health institutions were more likely to experience needle stick and sharp injuries than those working in government health institutions. This might be due to private health sectors did not have the required number of health personnel and workload is attributable to the risk of exposure and training on infection prevention is less likely to be conducted.

The other factor is the work experience of healthcare workers; healthcare workers with less work experience were more likely to experience needle stick and sharp injuries as compared to those who had more work experience. This finding is consistent with studies conducted in Ethiopia, Egypt, Tanzania and Tehran. ${ }^{24-28}$ The possible reason might be less experienced workers are in a stressful situation in the workplace, they are less likely to get training, they did not know how to process and handle used sharp instruments, and even they might not be much concerned about the consequence of injury compared to experienced workers.

Concerning the workload of healthcare workers, healthcare workers providing healthcare services for more than the mean were more likely to experience needle stick and sharp injuries than healthcare workers serving below the mean were. This finding is in line with a study conducted in Egypt. ${ }^{25}$ This might be due to a lack of concentration that is tiredness and hastiness to win the workload.

The availability of sharp storage and disposal containers is the other factor that was significantly associated with needle stick and sharp injuries. Healthcare workers who had sharp storage and disposal container all the time in their workplace were less likely to experience needle stick and sharp injuries than those who did not have. This finding is supported by a study conducted in Egypt. ${ }^{29}$ This might be possible because participants were asked to remember their entire work time and the one-year experience of needle stick and sharp injuries.

Recall bias might be a major problem especially in recalling the frequency of injuries. Besides, the sample size used might not be large enough to detect the difference of the occurrence of the outcome variable on the explanatory variables that are declared as not statistically significant.

\section{Conclusions}

The prevalence of needle stick and sharps injury was high. Type of working institution, work experience, workload (number of patients served per day) and availability of 
sharp storage and disposal container were significantly associated with needle stick and sharp injuries. Therefore, efforts have to be made to reduce the workload of healthcare workers by recruiting an adequate number of work force. Besides, health institutions need to avail and ensure the availability of sharp storage and disposal means all the time in the workplaces.

\section{Data Sharing Statement}

The datasets used and/or analyzed during the current study are available from the corresponding author on reasonable request.

\section{Ethics Approval and Informed Consent}

The study was conducted following the Declaration of Helsinki. Ethical clearance was obtained from the Institutional Review board of the College of Medicine and Health Sciences, Wollo University. Permission letter to conduct the study was obtained from the Dessie city administration health office and respective health institutions. Written informed consent was obtained from healthcare workers after they were informed about the objectives and procedures of the study. Their rights to refuse participation any time they want were assured. For this purpose, a one-page consent letter was attached as a cover page of each questionnaire stating the general objective of the study and issues of confidentiality that was discussed by the data collectors before proceeding to the data collection.

\section{Acknowledgments}

I am grateful to Wollo University, Dessie city health staffs and study participants for their valuable contribution during the study.

\section{Author Contributions}

The author made substantial contributions to conception and design, acquisition of data, analysis and interpretation of data, took part in drafting the article and revising it critically for important intellectual content, agreed to submit to the current journal, gave final approval of the version to be published and agreed to be accountable for all aspects of the work.

\section{Funding}

There is no funding to report.

\section{Disclosure}

The authors report no conflicts of interest for this work.

\section{References}

1. Moazaam A, Zaid A, Beshyah RL. Needle stick injuries: an over view of the size of the problem, prevention and management. Ibnosina J Med Biomed Sci. 2010;2(2):53-61. doi:10.4103/1947489X.210971

2. Hashimi A, Reesh SA, Indah L. Prevalence of needle stick and sharp injuries among health care workers, Najran Saudi Arabia. Epidemiol. 2012;2:117. doi:10.4172/2161-1165.1000117

3. Zewdie A. Assessment on magnitude of needle stick and sharp injuries and associated factors among health care workers in East Gojam Zone health institutions, Amhara Regional State, Ethiopia. Glob J Med Res. 2013;8(3):41-50.

4. Birhanu E. Prevalence and determinant factors for sharp injuries among Addis Ababa hospitals health professionals. Sci J Public Health. 2013;1(5):189-193. doi:10.11648/j.sjph.20130105.11

5. Lulie W, Emebet A, Medihanit T, et al. Factors associated with needle stick and sharp injuries among health care workers in Felege Hiwot referral Hospital, Bahir Dar, North West Ethiopia. Int J Infect Control. 2012;9(4):1-9.

6. Amira CO, Awobusuyi JO. Needle stick injury among health care workers in haemodialysis unit in Nigeria: a multi-center study. Int J Occup Environ Med. 2014;5:1-8.

7. Tadesse A. Assessment of health care workers occupational exposure to HIV and post exposure prophylaxis (PEP) in health centers and hospitals of Addis Ababa. Int J Infect Dis. 2008.

8. WHO. Sharp Injuries: Global Burden of Disease from Sharp Injuries to Health Care Workers. Geneva: World Health Organization 2003.

9. Reda AA, Fisseha S, Mengistie B, et al. Standard precautions: occupational exposure and behavior of health care workers in Ethiopia. PLoS One. 2010;5(12):e14420. doi:10.1371/journal.pone.0014420

10. Susan Q, Wilburn BSN, Gerry EL. Preventing needle stick injuries among health care workers: WHO-ICN collaboration. International Journal of Occupational Environmental Health. 2004;10:451-456. doi:10.1179/oeh.2004.10.4.451

11. Ayalu R, Shiferaw F, et al. Occupational exposure and behavior of health care workers in Ethiopia. PLoS One. 2010;5(12):e14420.

12. Yosef WG. Assessment of the Safety of Injections and Related Medical Practices in Health Institutions at Sidama Zone. SNNPRS; 2004.

13. Wilburn S. Needle stick and sharp injury prevention. Online J Issues Nurs. 2004;9(3):4.

14. Desta H, Aman J, Morankar S, et al. Effectiveness of training on standard precautions to prevent needle stick injuries among health professionals: a systematic review. JB Libr Syst Rev. 2012;10:40.

15. WHO Needle Stick injuries. Available from: www.who.int/occupa tional-health/topics/needinjuries/en/indox1.html. Accessed October 23, 2020.

16. Hanafi M, Mohammed A, Kassem MS. Needle stick injuries among health care workers of University of Alexandria Hospital. East Mediterr Health J. 2011;17(1):26-35. doi:10.26719/2011.17.1.26

17. Fredrich MN, Jaakkola MS. Needle stick injuries among nurses in sub-Saharan Africa. Trop Med Int Health. 2005;10(8):773-781. doi:10.1111/j.1365-3156.2005.01453.x

18. Wainaina AM Prevalence and determinant needle stick injuries at Kenyatta national Hospital, Nairobi, Kenya. Available from: http:// hdl.handle.net/11295/61091. Accessed October 23, 2020.

19. Everline M, Zipporah N, peter W, Jared O. Prevalence and factors associated with percutaneous injuries and splash exposures among health care workers in a provincial Hospital, Kenya. Pan Afr Med J. 2013;14:10. 
20. Shiao J, Chuang YE, Vuang KY. Needle stick and sharp injuries among health care workers in Taiwan. Epidemiol Infect. 2009;122 (2):259-265

21. Tadesse M, Tadesse T. Epidemiology of needle stick injury among health care workers in Awasa City, Southern Ethiopia. Trop Doct. 2010;40(2):111-113. doi:10.1258/td.2009.090191

22. Beyene H, Yirsaw BD. Occupational risk factors associated with needlestick injuries among health care workers in Hawassa city, Southern Ethiopia. Occup Med Health Aff. 2014;2:156. doi:10.4172/ 2329-6879.1000156

23. Getahun K, Mesafint M, Hardeep RS. Needle stick and sharp injuries among health care workers in Gondar city, Ethiopian. Saf Sci. 2012;50(4):1093-1097. doi:10.1016/j.ssci.2011.11.017

24. Robel M, Henok Y, Kidist T, Firehiwot T, Imam D. Magnitude and impact of occupational related needle stick and sharp injuries and associated factors among health care workers in Dire Dawa, Eastern Ethiopia. Med Saf Glob Health. 2018;7:1. doi:10.4172/25740407.1000141
25. Abebe D, Desalegn A, Tenaw G. Occupational exposure to needle stick and sharp injuries and associated factors among health care workers in Awi Zone, Northwest Ethiopia. J Environ Public Health. 2017;6. doi:10.1155/2017/2438713

26. Jaber P, Nazanin I, Farideh G. Factors associated with needle stick and sharp injuries among health care workers. IJOH. 2013;5:191-197.

27. Kebede A, Gerensea H. Prevalence of needle stick injury and its associated factors among nurses working in public hospitals of Dessie town, Northeast Ethiopia, 2016. BMC Res Notes. 2018;11 (1):413. doi:10.1186/s13104-018-3529-9

28. Phillipo C, Jeremiah S, Martha M, et al. Needle-stick injuries and splash exposures among health-care workers at a tertiary care hospital in north-western Tanzania. Tanzan J Health Res. 2015;17. doi: $10.4314 /$ thrb.v17i2.3

29. Ahmed A. Needle stick injuries: risk factors among tertiary care hospital workers in Egypt. Int J Med. 2018;111(suppl_1): hcy200.121. doi:10.1093/qjmed/hcy200.121
Risk Management and Healthcare Policy

\section{Publish your work in this journal}

Risk Management and Healthcare Policy is an international, peerreviewed, open access journal focusing on all aspects of public health, policy, and preventative measures to promote good health and improve morbidity and mortality in the population. The journal welcomes submitted papers covering original research, basic science, clinical \& epidemiological studies, reviews and evaluations,
Dovepress

guidelines, expert opinion and commentary, case reports and extended reports. The manuscript management system is completely online and includes a very quick and fair peer-review system, which is all easy to use. Visit http://www.dovepress.com/testimonials.php to read real quotes from published authors. 